\title{
The Relationship between Information and Communication Technologies and New Organizational Forms: Reference of the manufacturing industry in the area of Carabobo,Venezuela
}

\author{
Francisco García Fernández (I), Ana Emilia Cordero Borjas (2)
}

\begin{abstract}
The objective of the present paper is to determine the influence of Information and Communication Technology (ICT) on Organizational Performance and the configuration of the New Organizational Forms (NOF) in a group of manufacturing companies from the region of Carabobo,Venezuela. Circumscribed in a non-experimental research context, with a transactional - correlational design, a questionnaire with eight items was designed. This instrument allowed to calculate the Pearson's correlation coefficient in order to determine the correspondence between variables. This questionnaire was administered to a random sample of 19 companies of the manufacturing industry. Finally, it was determined that a positive influence exists of the ICT on Organizational Development and the NOF; however, it is acknowledged that the correlation on the majority of the variables studied is positive but weak. This is accounted for the existence of other variables that may also have an influence on the decisions in the organizations.
\end{abstract}

Keywords: Knowledge Based Economy, Information and Communication Technologies (ICT), New Organizational Forms, Job Organization.

(I) Unidad Académica Multidisciplinaria de Comercio y Administración Victoria. Universidad Autónoma de Tamaulipas, México. 20 de noviembre 168 B Zona Centro, CiudadVictoria,Tamaulipas.Teléfono: 528343 I8I756 Ext. I40. Correo Electrónico: ffernandez@uat.edu.mx (2) Facultad de Ciencias Económicas y Sociales. Universidad de Carabobo Av. Salvador Allende, Naguanagua, Estado Carabobo,Venezuela. Teléfono: 58 24I 86703I5. Correo Electrónico: acordero2@uc.edu.ve 


\section{Introduction}

Since the last decade of the 20th Century, the accelerated development of the technological change has been linked to the spread of the ICTs in the productive and service sector in an important group of countries, especially in those which are highly developed. Both in the United States and the European Union, the informatics and communications sector functioned as one of the main motors of the economic growth, especially during the 1990s and early 2000s.

The rapid spread of the ICTs was conceptually accompanied by the appearance of the term Knowledge based Economy (KBE). Regarding this, Foray and Lundvall (1996) established the relationship between the two of them, stating that the system of the ICTs provides the KBE with a new and different technology base which changes radically the production and distribution conditions, as well as its assembly in the production system.

On the other hand, The Solow's question about the real connection between the ICTs and productivity (Solow's paradox), brought about different studies that, as in the case of Greenspan (2000) or Brynjolfsson (2003), enabled to establish clear signs of the existing positive relationship between productivity and the ICTs.

Now, at the enterprise level the possibility of taking advantage of those technologies' high potential depends on the strategies and structural changes that the sector's enterprises implement. With respect to this, Nelson (1991) has recognized that the structure, the strategy and the central capabilities are the features that define the character of a stable enterprise. Competitive enterprises adjust their structure to the changes in strategy despite the fact that that reorganization involves considerable costs for them.

According to Drucker (1998), organizations of the new era have witnessed the power of technology no only for its competitive capability, but also as agents promoting deep changes in the Organizational forms (OF). For this reason, the $\mathrm{New}$ Organizational Forms (NOF) that respond to the need to align strategy-structure- direction processes (Miles, et al., I991) are influenced by the profound changes in the environment, being technological and economical changes examples of those. From this perspective and taking into account the studies carried out by Chandler (1962) in which he demonstrates the relationship between the strategy and the structure based on a study carried out in a group of big North American corporations he raises the following question: Is there any influence of the ICTs on the Organizational Performance and the NOF configuration in a group of enterprises from the manufacturing sector in the area of Carabobo, Venezuela?

In order to answer this question, a co relational study was undertaken. Prior to the study, the literature on the role of the ICTs in the development of the Knowledge Based Economy $(\mathrm{KBE})$, the organizational changes and the New Organizational Forms (NOF) was reviewed. The second part is devoted to the methodology, in which the transactional correlational study is presented. For this study a survey was employed with measurement scales of reason and intervals in order to be able to calculate the Pearson's correlation from a random sample of 19 companies in the South Industrial Zone of Valencia, Venezuela. In the third part, the results are presented and a discussion is offered. In the last part the conclusions are outlined.

\section{Theoretical Perspective}

The impact of the new technologies on the most developed economies, in particular the American one, has been referred to as the New Economy by some economists (Brynjolfsson \& Greenspan among others). However, European authors associate the economical and technological change with the transition to the KBE (David, Foray \& Lundval among others). There are specialists who believe that they are not identical terms (New Economy, Information Society and Knowledge Society) and suggest successive developmental stages (Arcos Sánchez, 200I). Lundvall (2003) argues that KBE is above all a learning economy and states that: "In this new era a key issue is the capability to learn of the people, the organizations, the networks and the regions. Learning to deal with and use all the potential of the new technologies is, in a sense, what enables them to transform themselves from new ones into old ones" (p. 42).

The concept of KBE reflects a basic characteristic of the current organizations. This is about the key role that knowledge generation and use plays in the success of a country's organizations (Lundvall, 1992). Nowadays knowledge about how to generate and manage the economic activities, especially those that involve the application of new scientific and technological developments, has paramount importance. The more the scientific and technological contents of the economic activities increase the more important the organizational and management progress becomes. Therefore, knowledge is essential in the current economy due to its contribution to productivity increase, to the formation and growth of new industries, and to the organizational changes necessary to apply that new knowledge effectively.

\section{I.I Information and Communications Technologies in the Knowledge Based Economy.}

The increase in productivity in the productive sector would not 
be possible without a mediator mechanism through which that spread of knowledge on all the branches and sectors of the economic activity is produced. The ICT's have been that mediator mechanism. For scholars such as Lundvall (200I), and Steinmueller (200I), and other evolutionists, the extensive incorporation of the ICT's into the economy and society assumes a radical change, the transition into a new stage of development.

Lundvall (2003) states that we need to turn to the concept of Economical Technical Paradigm developed by Freeman and Pérez (1988) in the 80's in order to be able to understand the extent of the change that we face nowadays. The concept was accompanied by the term "key factor." For them, in each of the paradigms there is a "key or nuclear factor" that serves as vehicle for the spread of the technological revolution from one branch to another, and this is done at global level. This "key" factor exercises a decisive influence on the structure of the relative costs, capable of serving as spreading mechanism in all the economic system. This allows for the incorporation of the new paradigm into the common sense of the technology people, engineers and managers (Pérez, 1986).

Foray and Lundvall (1996) insist on the role of the knowledge based economic change:"The system of the ICTs provides the knowledge based economy with a new and different technology base that radically changes the conditions of knowledge production and distribution, as well as its assembly in the production system." However, a group of economists led by Greenspan (2000) addresses the theme from the angle of the effects that the ICT's produce on the productivity of the developed economies, especially on the American economy. This theme has been particularly controversial, especially because of the Solow Paradox. This paradox suggests that, despite the extensive use of the ICTs, these had not had a significant effect on productivity until the mid 90's.

Since the mid 90's the works of the professor Erik Brynjolfsson from the Massachussets Institute of Technology (MIT) among other researchers offered information that led to the solution of the paradox and also offered an explanation of the reasons why they had not been able to find positive evidence until that moment of the relationship between the ICTs and the productivity (Brynjolfsson, 2003). Authors such as Gordon (2000) did not consider those pieces of evidence convincing enough; the increase in productivity in the last decade of the past century in the North American economy were not generalized to all the economy; it was just concentrated on the productive sectors of informatics assets.

It is important to mention that both the evolutionists and the neoclassics agree on the idea that the effects of the ICTs on productivity are produced only in the long term (García
Fernández \& Cordero, 2007).

David (199I) has sustained that the institutional and the organizational adaptation period would always be long for a radically new technology. In addition to this, different studies have made clear that the positive effects of the ICTs demand a reform of the enterprise's organizational structure, creating the need of a an internal (an external) transformation that enables to extract all the benefits of such investment.

Regarding that, Ontiveros et al. (2004) states that "the ICTs are not the panacea and that the difference that the ICTs can provide is much more feasible only if they are more intimately accompanied by other competitive (not strictly technological) advantages, and perhaps, with the corresponding organizational adaptation" (p.|32).

Bresnahan et al. (1999) highlight that such reform implies transformations in other fields such as the resources supply, the organization and the innovation, in such a way that it is possible to take advantage of the supplementary items that are produced among all of them.

By the same token, Lundvall (2003) in a research project into the Danish economy demonstrated that the enterprises that introduced ICT without combining them with the investment in employee training, without making changes in the direction, and without modifying the job organization, had a negative effect on the productivity growth that extended for several years (Gjerding, 1996). These results were confirmed later in much more detail and with more precision by the Business and Industry Ministry of Denmark (Business and Industry Ministry, 1996)

Having the KBE as the context and the ICTs as "key factors" of the New Technical Economical Paradigm, the aforementioned issues confirm that the introduction of the ICTs as a competitive strategy in organizations needs to be accompanied by modifications of which one of the most outstanding is the reconfiguration of its OFs.

In the next section we will address the study of the main organizational forms that scholars recognize as the main structures that are designed by enterprises in order to implement the strategies previously selected by their administrators.

\section{I.2 New Organizational Forms, their origin in the ICTs.}

As Drucker (1998) has stated, the new era's organizations have witnessed the technology power, not only as a competitive capability, but also as an agent promoting profound changes in the OFs. 
According to Miles et al. (1997), the OFs represent "a logical manner of giving shape to the strategy, to the structure and to the processes of directing an organization as an effective whole" (p.7).The Strategy defines what will be done in an organization and the structure defines how it will be done. This is why Chandler (1992) proposes that the strategy be followed by the structure as in his study on Sears Roebuck, Standard Oil, Du Pont and General Motors found that, among other things, that a) every strategy that was implemented in such enterprises created administrative problems due to a lack of an adequate structure to carry it out; and b) the modification of the organizational structure enabled to manage the implementation of the strategy more effectively.

It is important to mention that the prevailing stability in the economic stages in the late XIX century and early XX century was characterized by long periods of stability and short periods of innovation, which are defined by Gates (2000) as "uninterruptedly constant instability (p. 534). Under this scenario, uncertainty is an important part of the system's performance. It acknowledges that the future is unpredictable; and therefore, the balance becomes conditioned by a complex environment.

This way the Organizational Forms correspond to the demands of their time and have evolved in three periods of time: standardization, personalization and innovation (Miles et al., 1997). Based on the work of García Fernández and Cordero (2007), the characteristics of the three periods of time and how the OFs evolved through them are presented in the next section:

a) The standardization period goes from the late century XIX through to the present. In this period the job division fosters specialization. This emphasizes the Time Economy; controls are exercised and imposed and big efforts are made in order to establish an efficient labor organization. Taylor, Fayol, and Weber contribute to what is called the classic management approach, in which "the most efficient and effective organizations had a hierarchical structure" (Kikta, 1999, p. 457).

b) The personalization period is conditioned by a competitive market, which clearly started in the 60 's. The quality associated with competitiveness as a fundamental factor in the definition of NOF, challenges the concept of individual posts with simple and fragmented tasks; the need of redefining the organization's structure emerges, considering that, in order to attain this "there is no an optimal way of organizing; that is to say, any organization wanting to become effective will have to ensure the congruence among its structure, its internal processes and the specific circumstances or contingencies that characterize it" (Morgan, 1996, pp. 29-64).

The Industrial Organization, framed on the industrial economy, is at its very peak and the theoretical and empirical works published during that period (Buzzell y Gale, 1987; Caves y Porter, 1977; Lamb 1984; Porter, 1980, 1981; Schmalensee, 1985;) confirms that the OFs were oriented towards linking the IT's effectiveness as a competitive advantage per se. However, these pieces of work failed to identify or recognize the value that the IT's management produced.

Up until now adaptation is a fundamental factor for the survival of a competitive market. The organization is not recognized as a whole that interacts with the environment and that modifies and is modified by it. This stems from identifying the group of endogenous resources that will support the organization's existence; such identification emerges during the innovation period.

c) The innovation period (late 80's) places a strong emphasis on the continuous process of innovation and knowledge generation, being its management fundamental for the consolidation of it as an asset and a differentiating factor of organizations (Miles et al., 1997). In this period the people's holistic development is sought through a community that favors innovation and creativity without leaving aside concepts such as authority, control, or leadership. In the XXI century, dominated by the KBE, the organizations require fluid, flexible and complex working relationships which increase their ability to obtain, process and use information under interdependent conditions (Gallardo et al., 1999).

As García Fernández and Cordero (2007) summarize, the most relevant OFs during this innovation period are: a) the Adhocracy Form (Mintzberg 1984), b) the Hypertext Form (Nonaka y Takeuchi, 1995), c) the Hypertrebol Form (Rodríguez Antón, et al, 200 I), d) the Network Form (Miles y Snow, 1986), and e) the Work Teams.

a) The Adhocracy Form. It is characterized by the horizontal differentiation and a great deal of decentralization. Toffler (1993) Points out that the adhocracy is an enterprise's way of living, which goes beyond the existence of internal small groups. This also enables the enterprise to mold itself with promptness and flexibility in a complex and changing environment. In order to react to these changes, inter-functional coordination is stimulated.

b) Hypertext form. It is a network organization based on the organizational knowledge and learning, which can create some relationship forms and interactions through both internal and external telematics networks. It is an OF made up of a superposition of layers or stratums made whose goal is to serve as a structural base for the creation of organizational knowledge. Just as in a software application, "the hypertext allows the user 
to access several layers" (Nonaka y Takeuchi, 1995). These layers are: the project teams, knowledge base and the business system.

c) Hypertrebol form. This OF combines the Nonaka and Takeuchi's (1995) Hypertext form and Handy's (1995) Hypertrebol form; team work is strengthened in order to promote the innovation process through the establishment of projects.

d) Network form. It is characterized by the total flattening of its structure since authority is based on knowledge and not on hierarchical levels. Both internal and external relationships are of paramount importance; through these, constant information flows, allowing the organizational inter and intra communication (Miles et al, 1997).

e) Work Teams. The OFs described above may constitute a Work Team (WT) in themselves. However, in order for an organization to be considered as taking this organizational form, it needs to meet certain requirements and principles: a culture based on the collective commitment, the continuity of the social interactions, the creation of a reciprocal awareness, the stability of relationships in time and the structure of roles
(Olmsted, 1989).

\section{Methodology}

\subsection{Nature of the research}

According to the level of investigation the study is considered correlational. Data was collected and analyzed with the objective of determining whether there was an influence of the ICTs on some organizational performance variables of a group of enterprises. The study also sought to determine whether OFs are configured as a result of this influence. These enterprises were selected from the manufacturing sector in the Carabobo region. In order to attain the proposed objective a non-experimental study was carried out with strong emphasis on a transactional correlational design.

In order to do so a survey was used as the main data-collection instrument. It was administered to executives of the human resources or administration departments of 19 enterprises from the manufacturing sector located in the South industrial zone of Valencia, Venezuela. The following figure shows the variables and dimensions to be correlated.

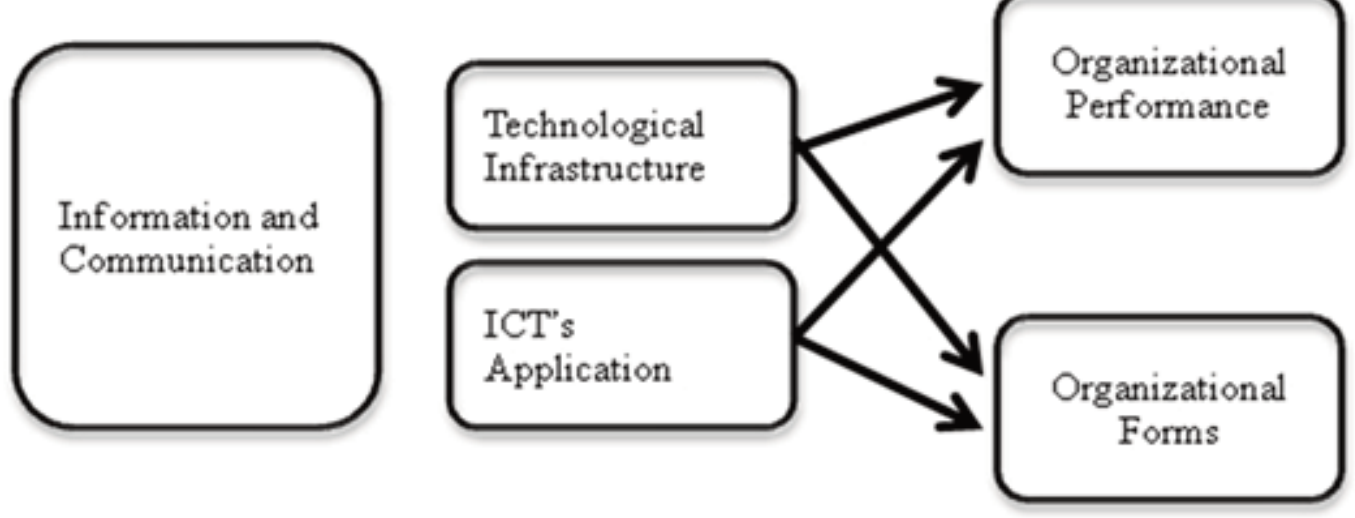

Figure I:Variables and Dimensions to be correlated

Where:

I) Organizational performance variables: a) Value chains, b) Efficiency and c) Organizational Variables.

2) Organizational forms:a) Types of plans and b) Elements of the organizational structure.

\subsection{Data- collection instrument}

Based on the information described above and taking into account the objective of the present study, the researched variables are:
I) Information and Communication Technologies: Through the ICT Infrastructure (Communication Networks, Computers, Corporative Telephone System and Local Network Area) and their application.

2) Organizational Performance:Advantages of the ICTs in the Value Chain; Efficiency in the Supply Chain, Internal Operations and Distribution Channel; and a group of selected Organizational Variables such as: Quality, Response Capability, Competitiveness, Organizational Connectivity, Costs, Productivity and Sales.

3) Organizational Forms: Types of Plans (Strategies, Policies, 
Rules and Procedures); Organizational Structure (Division of Labor, Departmentalization, Span of Control, Chain of Command, Formalization and Decentralization); and the adopted Organizational Forms (Adhocracy, Hypertext, Hypertrebol, Network Form and Work Teams)

Based on the central research variables, a questionnaire was designed in which eight (8) items are included.These items link the ICTs in terms of Technological Infrastructure and Application in the researched organizations with the Organizational Performance and Organizational Forms of them. To do so, dichotomy statements or various alternatives are presented. The latter are presented through a five (5) point Lickert Scale.

Measuring the variables in an interval and reason level enabled to administer a statistical test for the inferential analysis among such variables being studied. It is important to mention that a descriptive analysis was carried out. An inferential analysis was later conducted through the Pearson's correlational coefficient due to the correlational nature of the present study. The questionnaire was subject to the judgment of experts who provided feedback and suggestions which were incorporated into the design of the final draft of it. The instrument's reliability was measured using the Cronbach Alpha's reliability's coefficient; the questionnaire was administered to a pilot sample in order to calculate such coefficient. It can be affirmed (after the Cronbach Alpha has been calculated) that the designed questionnaire is
$90 \%$ reliable, which can be considered a high stability of it.

\subsection{Characteristics of the sample}

As was mentioned before, the present study made use of an instrument which included statements associated with the three (3) inter-related variables. This was done in order to determine the influence of the ICTs on the Organizational Performance of a group of enterprises selected form the manufacturing sector in the region of Carabobo, Venezuela. The study also sought to identify the OFs that are configured as a result of this influence. In order to do so, there was a need to administer the designed instrument to 19 enterprises located in the South Industrial Zone of Valencia, Venezuela.

The sample used is of probabilistic nature. In order to calculate its size, a population of $3 \mathrm{I}$ enterprises was considered.According to CONINDUSTRIA (2005) these enterprises belong both: first to the Great Industry and second to the manufacturing sector of the South Industrial Zone in Valencia.The sample size was calculated taking into account the following criteria:Population: 3 I enterprises; level of trust: $90 \%$, and Maximum Permissible Error: $12 \%$, obtaining a sample of 19 enterprises.

A stratified sample was used in which it was made clear that these 19 enterprises represent $61 \%$ of the entire population. The following table characterizes the selected sample:

Characterization of the simple according to the International Classification of Uniform Industries (CIIU Rev. 4) from the United Nations

Table I: Enterprises surveyed in the city of Ciudad de Valencia, Venezuela.

\begin{tabular}{|c|c|c|}
\hline $\begin{array}{c}\text { CIIU Rev. 4. Section C. Manufacturing } \\
\text { Industry }\end{array}$ & \multicolumn{2}{|c|}{ Number of Enterprises } \\
\hline $\begin{array}{l}\text { Division } \\
\end{array}$ & Population & Sample \\
\hline Division: $10-$ Manufacturing of food products & 6 & 4 \\
\hline $\begin{array}{l}\text { Division: } 17 \text { - Manufacturing of paper and paper } \\
\text { products }\end{array}$ & 4 & 2 \\
\hline $\begin{array}{l}\text { Division: } 20 \text { - Manufacturing of substances and } \\
\text { chemical products }\end{array}$ & 4 & 3 \\
\hline $\begin{array}{l}\text { Division: } 22 \text { - Manufacturing of rubber and plastic } \\
\text { products }\end{array}$ & 3 & 2 \\
\hline $\begin{array}{l}\text { Division: } 25 \text { - Manufacturing of products derived } \\
\text { from metal, except machinery and equipment }\end{array}$ & 5 & 3 \\
\hline $\begin{array}{l}\text { Division: } 29 \text { - Manufacturing of auto motors vehicles, } \\
\text { trailers, and semitrailers }\end{array}$ & 9 & 5 \\
\hline
\end{tabular}




\section{Results and Discussion}

\section{I Descriptive analysis}

A descriptive analysis of each of the variables will be provided in the following section in order to distinguish the indicators' behavior:

\section{A) Information and Communication Technologies:}

With respect to the collected data it was possible to confirm that:

I. Regarding the infrastructure: all the participating organizations have Internet connection, of which 16 have desk computers and corporate telephone system; 15 have Intranet, laptop computers, corporate cell telephone system and a local area network (LAN). Few organizations have Extranet and Personal Digital Assistance (PDA).

2. Regarding the Application: the most frequent applications are: use of e-mail and customer services; the second most frequent application is the interaction with government organizations. It is important to note that within the group of ICTs possible applications the least frequently used are the search engines and electronic trade.

\section{B) Organization performance:}

When analyzing some of the variables that describe the surveyed organizations' performance, the following can be highlighted:

I. Benefits of the ICTs on the Value Chain: the Value Chain's activities most benefited by the ICTs are: General Administration, Human Resources Management, Technologies and New Products Development, and Sales and Marketing

2. Impact of the ICTs on the following processes' efficiency: Based on the collected data it can be concluded that the Supply Chain has been positively impacted by the introduction of the ITCs since most of the researched organizations confirm that Similarly, the Internal Operations and the Distribution Channel processes have been impacted positively. However, the latter process was benefited by the ICTs in slightly more than $50 \%$ of the enterprises.

3. Organizational Variables: all organizational variables were significantly impacted by the ICTs, especially: Response Capability, Competitiveness, Organizational Connectivity, and Sales.

C) Organizational Forms:
In order to attain the goal of the present research, and taking into consideration the importance of the OFs as the link among the Strategy, the Organizational Structure, and the Direction Processes, only the following issues were researched:

I.Types of plans: it is necessary to mention that in most of the surveyed organizations only the procedures are impacted by the ICTs since no congruence was found between the answers provided in relation to Strategies, Policies and Rules, which are only affected by the ICTs in $50 \%$ of the enterprises.

2. Elements of the Organizational Structure:According to the majority of the surveyed enterprises Division of Labor is the most impacted element when it comes to redefining the Organizational Structure due to introduction and utilization of the ICTs.With respect to Departmentalization, Span of Control, Command Chain, Formalization, and Decentralization are moderately affected by the ICTs variable.

3. Organizational Forms: after inquiring about the elements of the Organizational Structure, the researched organizations were asked to select the characteristics of the OFs that are configured as a result of the introduction of the ICTs and can be concluded that: 14 organizations have an Adhocracy OF, 3 have one Hypertext FO and one Hypertrebol FO. They are all linked to the utilization of the ICTs as a competitive advantage that enables them to adapt themselves to the environmental changes, to the exploitation of the Technological Infrastructure, and to the generation of innovative projects.

After a brief description of the most salient findings obtained through the administration of the instrument, a general picture of the researched variables is achieved.

\subsection{Inferential Analysis}

In order to determine whether there is influence of the Information and Communication Technologies on the Performance of a group of enterprises from the manufacturing sector in the Carabobo region, and the OFs that are configured as a result of this influence, an inferential analysis was carried out. This analysis was based on the Pearson's coefficient correlation. The determining coefficient was then calculated which led to a percentage analysis of a variable modification as a result of the modification of another. This allows to establish the relationship between the two of them.

\section{A) Influence of the Technological Infrastructure on the Applications:}

The Technological Infrastructure and the Application of the ICTs in organizations have a positive relation (Figure 2). Due 
to this, the technological infrastructure possessed by the researched organizations has a positive impact on the application of the ICTs.Among the elements that form part of the ICT infrastructure are the communication networks (internet, intranet, and extranet), the computers (desk and laptops), the corporate telephone systems (fixed and cell) and the Local Area Network (LAN).
It is necessary to point out that the application of the ICTs in these organizations accounts for $20 \%$ through the Technological Infrastructure possessed by them. Because of this, it can be inferred that, although there are different variables that can have an influence on the application of the ICTs, there is a relationship between these two variables (Infrastructure and Application).
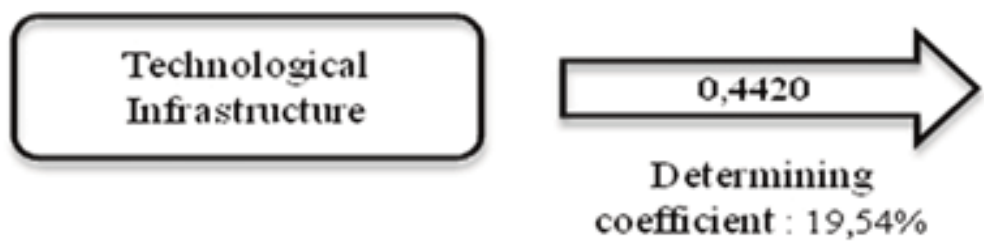

\section{Application of the ICTs}

Figure 2:Technological Infrastructure Correlation --- Application of the ICTs

B) Influence of the Technological Infrastructure on the Organizational Performance and the Organizational Forms:

There is a weakly positive relationship between the Technological Infrastructure and: a) the Organizational Performance, and b) the Organizational Forms (Figure 3). First of all, it can be concluded that the Technological Infrastructure possessed by the researched organizations benefit the Chain Value activities (General Administration, Human Resources Management, among others); improve the efficiency of the Supply Chain, the Internal Operations and the Distribution Channel and have a positive impact on quality, productivity and sales, among other indicators.

It is important to recognize that the correlation between the two groups is positive, but weak; therefore, it can be concluded that after the determining coefficient was calculated, generally speaking, there is a group of variables that, as is the case with the ITCs, impact on the Chain Value activities, efficiency and other Organizational Performance indicators.

Secondly, when linking the ICTs infrastructure with the elements of the OFs (planning-Structure), there is a greater influence of the Infrastructure on the types of plans (strategies, policies, rules and procedures) than on the elements of the organizational design (division of labor, departmentalization, span of control, among others).

In the case of the determining coefficient, this permits to conclude that the ICTs Infrastructure has a greater impact on the Planning of the group of the researched enterprises than on the Structure of them. It can be interpreted that there are variables with a greater impact when it comes to designing the organizational structure than the technological variable. However, this was not the case with the definition of the plans, where this variable shows more influence within the variables to be considered for the definition of strategies, rules, and procedures.

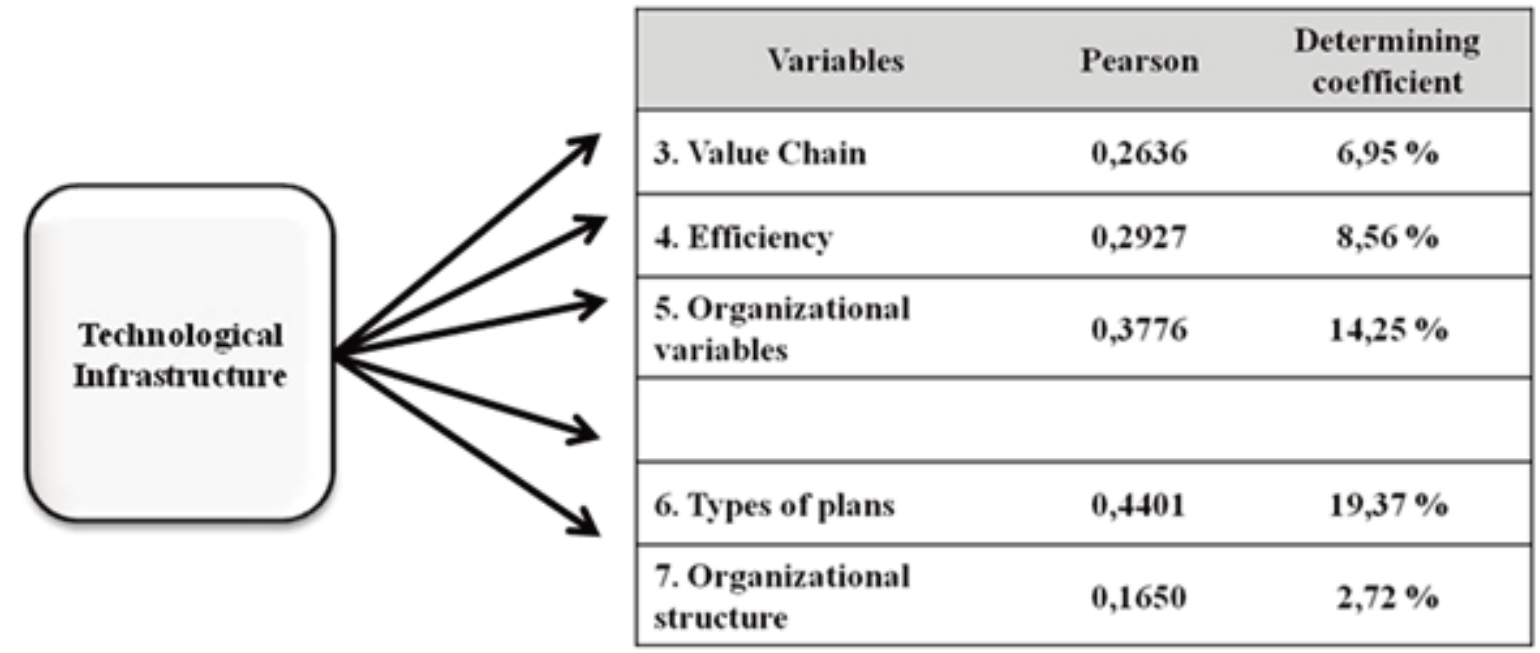

Figure 3: Co-relation Technological Infrastructure - Organizational Performance and the Organizational Forms 
C) Influence of the Application of the ICTs on the Performance and the Organizational Forms:

There is a moderately positive relationship between the Application of the ICTs and:a) Organizational Performance and b) the OFs (Figure 4). First of all, it can be concluded that the Application of the ICTs in the researched organizations has a positive influence on the Chain Value activities; improve the efficiency of the Supply Chain, the Internal Operations and the Distribution Channel and have a positive impact on the researched organizational variables. The efficiency of the different activities and processes of the organization are specially benefited by the application of the ICTs available.

With respect to the determining coefficient, after comparing the influence of the ICTs infrastructure with the application of them, it can be concluded that, generally speaking, there is a greater impact of the Application of the ICTs within the possi- ble group of variables that can influence the general Performance of these organizations that the technological infrastructure itself.

Second, when the Application of the ICTs is linked with the elements of the OFs (Planning - Structure), there is (as is the case with the ICT Infrastructure variable) a greater impact on the types of Plans than on the elements of organizational design.

In the case of the determining coefficient, it can be interpreted that the Application of the ICTs does not have a considerable impact on the organizational design either, inferring that there are other variables (which are beyond the scope of this study) that also have an impact on it.

Once again, the definition of the plans appears to be more connected to the Application of the ICTs.

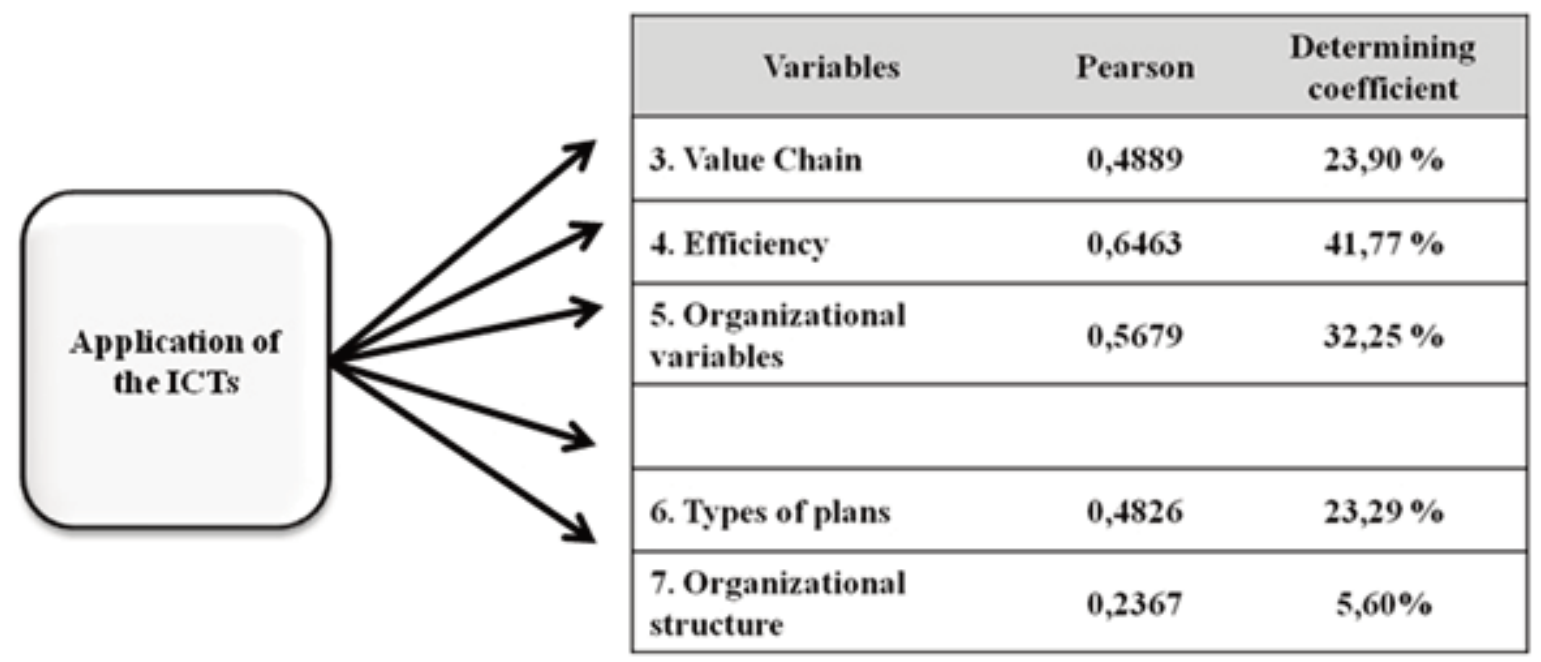

Figure 4: Correlation Application of the ICTs - Organizational Performance and the OFs 


\section{Conclusions}

The KBE reflects the transition from the economy to a status where the - scientific, technological or organizational - knowledge plays a crucial role in the success of enterprises and countries. A key element of this success is associated with the introduction of the ICTs. These are the material infrastructure that make possible any organizational change associated with the introduction of new knowledge. This is so because when the information is generalized and re-distributed within the organization, the reforms of the organizational structuree and the OFs become possible. Therefore, the introduction of the ICTs as a competitive strategy that functions as inter-mediator between the enterprise and the social environment merits a group of modifications. These modifications will need to be made in order to guarantee the proper exploitation of all the advantages and benefits of the ICTs as a key factor in the new economic paradigm, and therefore, in the new organizational paradigm by which the KBE is characterized.

The present research emerged out of the wide range of expectations generated in organizations due to the introduction of ICTs to the productive network. The dissemination of the ICTs at the enterprise level opens the possibility of taking advantage of the benefits that they offer. However, those benefits not only depend on the existence of ICTs infrastructure, but also on the way they are used and on whether or not they are seen as a strategy that makes a difference and that generates added value to the organizations.

This becomes evident in the organizational performance, preceded by the implementation of plans and vital structural changes that link the introduction of the ICTs as a strategy, with the other types of plans and components which define the organizational structure.

After the instrument was administered to 19 enterprises from the South Industrial Zone in the city of Valencia and the Pearson co-relation coefficient and the determining coefficient were calculated, the research question can be answered. Such research question was aimed at determining whether or not there was influence of the ICTs on the Organizational Performance and the configuration of NOF's of a group of enterprises from the manufacturing sector in the Carabobo region.

Scholars such as Miles et al. (1997) point out that the NOFs meet the need to align strategy - structure - direction processes, impacting directly on the organizational performance. Based on this argument and the theoretical references mentioned above, the three (3) variables (ICTs, Organizational Performance, and OFs) established for this study were corre- lated and analyzed. It can be concluded that:

I.There is a positive relation between:a) the ICT Infrastructure that the researched organizations have and the way in which it is used, b) the ICTs Infrastructure and the Organizational Performance, c) the ICT Infrastructure and the OFs, d) the ICTs Application and the Organizational Performance, and f) the ICTs Application and the OFs.

2. The degree of correspondence between the involved variables, although positive, in most of them it is only weakly positive, except for the ICTs Application which has a moderately positive impact on the efficiency and on the organizational variables.

It is necessary to stress that, although it was possible to determine that there is influence of the ICTs on the Organizational Performance and the configuration of the NOFs in the Group of researched organizations form the manufacturing sector in the region of Carabobo, the existence of other variables (customers, suppliers, competitors, government, among others) needs to be considered. These variables, as is the case with ICTs, also have an impact on the organizational decisions regarding the establishment of plans and the structure which help achieve the expected performance.

\section{References}

ARCOS SÁNCHEZ, T. (200I). Luces y sombras de la Nueva Economía y la Sociedad de la Información y el Conocimiento. Información Comercial Española, 793, 87-97.

BRESNAHAN, T., Brynjolfsson E. \& Hitt L. (1999). Information Technology, Workplace Organization and the Demand of Skilled Labour: Firm Level Evidence. Quarterly Journal of Economics, I I 7 , 339-376.

BRYNJOLFSSON, E. (2003). The IT Productivity GAP. Optimize Magazine, Julio, Issue 2I. Retrieved from de web January 8, 2008. http://ebusiness.mit.edu/erik/Optimize/pr_roi.html

CHANDLER, A. (1962). Strategy and Structure. Chapters in the history of the American Industrial Enterprise. Massachusetts: MIT Press.

DAVID, P. A. (I99I). The Dynamo and the Computer: The Modern Productivity Paradox in a Not-Too-Distant Mirror. In OECD, Technology and Productivity: The Challenge for Economic Policy (pp. 3 I5-345). Paris: OECD. 
DOSI, G. (1998). Sources, procedures and microeconomic effects of innovation. Journal of Economic Literature, 26 (3), II 20II7I.

DRUCKER, P. (1998). La organización del Futuro. Buenos Aires: Gránica.

FORAY, D. \& Lundvall B-A (1996). The knowledge-based economy: from the economics of knowledge to the learning economy. In D. Foray y B-A Lundvall (Eds.) Employment and Growth in the Knowledge-based Economy (pp. II-32). Paris: OECD Documents.

FREEMAN, C. \& Pérez C. (1988). Structural Crisis of adjustment, business cycles and investment behavior. En G. Dosi et al. (Eds.), Technical change and Economic Theory (pp. 38- 67). Londres: Pinter Publisher.

GALLARDO A., Camargo, M. \& Magallón, M. (1999). Rediseño Organizacional y la Organización que Aprende. Revista Gestión y Estrategia, 15. Retrieved from de web October 8, 2007. http://www.azc.uam.mx/publicaciones/gestion/num I5/doc08.ht $\mathrm{m}$

GARCÍA FERNÁNDEZ, F. \& Cordero A. (2007). Equipos de trabajo: forma organizativa de la economía basada en el conocimiento. Economía y Sociedad, 20 (13), 17-33.

GARCÍA FERNÁNDEZ, F. \& Cordero A. (2008). Los equipos de trabajo: una práctica basada en la gestión del conocimiento. Visión Gerencial, 7 (I), 45-52.

GATES,W. (2000). Los negocios en la era digital. Cómo adaptar la tecnología informática para obtener mayor beneficio. Traducción de J.A. Bravo. Barcelona: Editorial Plaza \& Janés Editorial, S.A.

GJERDING,A. (1996). Organizational innovation in the Danish private business sector. In DRUID Working paper Nro. 96-16, department of business Studies, Aalborg University. Retrieved from de web October 24, 2007. http://www.druid.dk/uploads/tx_picturedb/wp96-I6.pdf

GORDON, R.J. (2000). Does the "New Economy" Measure up to the Great Inventions of the Past? Working Paper, 7833, august de 2000. Massachusetts: NBER.

GREENSPAN,A. (2000). The Revolution in Information Technology. The Federal Reserve Board. Documento presentado en la Boston College Conference on the New Economy, Boston, Estados Unidos.
HANDY, C. (1995). La era de la sinrazón. Barcelona: Parramón,

KIKTA, P. (1999). Estructura Organizacional: la reestructuración de la organización para el siglo XXI. En Administración Total de Mejoramiento Continuo. Bogotá: Harrigton, J. Editorial Mc Graw Hill.

LUNDVALL, B-A (1992). National Innovation Systems:Towards a Theory of Innovation and Interactive Learning. Londres: Pinter Publisher.

LUNDVALL, B-A (200I). Innovation policy in the globalizing learning economy. In D.Archibugi y B-A Lundvall (Eds.) The globalizing learning economy (pp. 273-3 I0). Oxford, Inglaterra: Oxford University Press.

LUNDVALL, B-A (2003). ¿Por qué la nueva economía es una economía del aprendizaje? In F. Boscherini, M. Novicky y G. Yoguel (Eds.), Nuevas Tecnologías de Información y Comunicación. Los límites de la Economía del Conocimiento (pp. 39- 55). Buenos Aires: Ediciones Miño y Dávila, Universidad Nacional de General Sarmiento.

MILES, R. \& Snow C. (1986). Organizations: New Concepts for New Forms. California Management Review, 3 (28), 62-73.

MILES, R., Snow, C., Mathews, J., Miles, G. \& Coleman, H. (1997). Organizing In The Knowledge Age:Anticiping The Cellular Form. Academy of Management Executive, 4 (I I), 7-20.

MINTZBERG, H. (1984). La estructuración de las organizaciones. Barcelona:Ariel.

MORGAN, G. (1996). Imágenes de la organización. México: Editorial Alfaomega Grupo editor.

NELSON, R. (1991). The Role of Firm Differences in an Evolutionary Theory of Technical Advance. Science and Public Policy, 18 (6), 347-352.

NONAKA, I y Takeuchi H. (1995). The Knowledge-creating company. How Japanese companies create the dynamics of innovations. New York: Oxford University Press.

ONTIVEROS, E., Manzano D. y Rodríguez I. (2004). Tecnologías de la Información y de las Comunicaciones (TIC), crecimiento económico y actividad empresarial. Madrid: Círculo de Empresarios.

OLMSTED, M. (1989). Pequeño grupo. Barcelona: Paidós. 
PÉREZ, C. (1986). Las nuevas tecnologías: una visión de conjunto. In C. Ominami (Eds.), La Tercera Revolución Industrial (pp.43- 89). Buenos Aires: Grupo Editor Latinoamericano, RIAL.

RODRÍGUEZ, A., Morcillo, P., Casani, F. y Rodríguez J. (200 I, Septiembre). Propuesta de un nuevo modelo de estructura organizativa ante el reto de la nueva economía: las estructuras hipertrébol. Documento presentado en el XI Congreso AECA. (26-28), Madrid, España.

STEINMUELLER, W. E. (200I). Las economías basadas en el conocimiento y las tecnologías de la información y la comunicación. Ciencia, tecnología y sociedad - Innovación tecnológica. Retrieved from de web January 17,2008. http://www.oei.es/salactsi/steinmuller.pdf

TOFFLER, A. (1993). La Tercera Ola. Barcelona: Plaza \& Janés Editores SA. 
STATISTICAL APPENDIX

\section{A. INFORMATION AND COMMUNICATION TECHNOLOGY}

A.1 A vailable ITC infrastructure

\begin{tabular}{lc}
\hline Technology & Businesses (\%) \\
\hline Internet & 100,00 \\
Intranet & 78,95 \\
Extranet & 42,11 \\
Personal Computer & 84,21 \\
Lap top & 78,95 \\
Personal D igital Assistant (PDA) & 31,58 \\
Corporate fix phone line & 84,21 \\
Corporate cell phone & 78,95 \\
Local Area N etwork (LAN) & 78,95 \\
\hline
\end{tabular}

A.2 ITC applications

\begin{tabular}{lc}
\hline Applications & Businesses (\%) \\
\hline Email & 78,95 \\
Search engines & 63,16 \\
Electronic Bank & 57,89 \\
E C ommerce & 26,32 \\
Government interaction & 68,42 \\
Customer service & 84,21 \\
O nline delivery & 47,37 \\
\hline
\end{tabular}

\section{B. ORGANIZATIONAL INDICATORS}

B.1 Benefits of the ICT on the value chain
Businesses (\%)
B.3 Impact on organizational variables

\begin{tabular}{lc}
\hline Variables & Businesses (\%) \\
\hline Q uality & 68,42 \\
Response capacity & 73,68 \\
Competitiveness & 78,95 \\
O rganizational Connectivity & 78,95 \\
Cost & 63,16 \\
Productivity & 68,42 \\
Sales & 78,95 \\
\hline
\end{tabular}

C. ORGANIZATIONAL FORMS

C.1 Plan redefinition

\begin{tabular}{lc}
\hline Types of Plans & Businesses (\%) \\
\hline Strategies & 52,63 \\
Policies & 36,84 \\
Rules & 52,63 \\
Procedures & 68,42 \\
\hline
\end{tabular}

C.2 Redefinition of 0 rganizational D esign

\begin{tabular}{lc}
\hline Elements & Businesses (\%) \\
\hline Division of labor & 63,16 \\
Department division & 42,11 \\
Chain of command & 47,37 \\
Span of control & 47,37 \\
Formalization & 42,11 \\
Decentralization & 42,11 \\
\hline
\end{tabular}




\begin{tabular}{lc} 
General Management & 78,95 \\
H uman Resource Management & 78,95 \\
$\begin{array}{l}\text { Technology and new products } \\
\text { Development }\end{array}$ & 78,95 \\
Distribution and internal lo gistics & 63,16 \\
Supply and internal logistics & 52,63 \\
O perations & 52,63 \\
Service & 57,89 \\
Sales and Marketing & 78,95 \\
\hline B.2 Efficiency Improvement & 63,16 \\
\hline Process & 57,89 \\
\hline Supply chain & \\
\hline Internal O perations & \\
\hline
\end{tabular}

C.3 Resulting O rganizational Forms

\begin{tabular}{lc}
\hline Alternatives & Businesses (\%) \\
\hline Adhocracy & 78,95 \\
Hypertext & 15,79 \\
Hypertrebol & 5,26 \\
N etwork & 0,00 \\
Team work & 0,00 \\
\hline
\end{tabular}

